(C) 1987 ISIJ

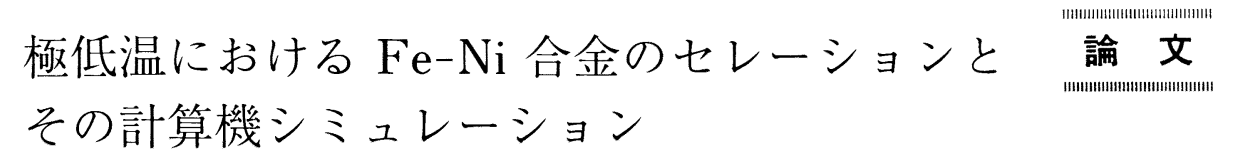

柴 田浩 司*.藤 田利夫*

\title{
Serration of Fe-Ni Binary Alloys at Very Low Temperatures and Its Computer Simulation
}

Koji Shibata and Toshio Fujita

\begin{abstract}
Synopsis :
Computer simulation of serrated plastic flow at very low temperatures has been investigated by comparing it with the deformation curves of $\mathrm{Fe}-\mathrm{Ni}$ binary alloys obtained in some coolants such as liquid helium. Simulation was carried out by dividing a specimen into small elements and calculating repeatedly some equations concerning the amount of deformation and the temperature change of each element during a short period of time. The equations were derived basically from the thermally activated dislocation motion and from the heat balance among heats converted from mechanical work, conducted in a specimen and exchanged with the coolant. It was concluded that the behavior of the serration and the accompanied phenomena could be reproduced fairly well by the simulation which did not have unreasonable assumption, whereas details of dislocation motion at cryogenic temperatures has not been clarified. The effects of some factors on the serration were discussed by using the simulation.

Key words : plastic deformation; mechanical testing; computer; simulation; high alloy steel; low temperature; helium ; serration; stress-strain curve ; tensile testing.
\end{abstract}

\section{1. 緒言}

$4.2 \mathrm{~K}$ 付近の極低温において金属材料を塑性変形する と，しばしば荷重-伸び曲線にセレーションが現れる. セレーションのおのおのの荷重低下時においては, 変形 が発熱を伴いながら高速度で局所的に生じる1) 5).この ような変形が極低温機器の構造部材で生じると場合によ つては構造物の力学的安定性や, 超伝導マグネットの正 常な運転に問題を生じることが䋰念される．また極低温 における疲労試験 ${ }^{5) 6)}$, 破壊䩲性試験 ${ }^{7)}$, クリープ試験 ${ }^{8)}$ などにおいてもセレーションあるいは発熱の影響が考え られ検討を要することも指摘されている ${ }^{9)}$. 七レーショ ンの生じかたは材料の種類 ${ }^{10111)}$, 試験片の太さ ${ }^{12)}$, 歪 み速度 ${ }^{13)}$ - 15), 試験機の剛性 ${ }^{16)}$, 試験温度 ${ }^{13) 15)}$ あるい は冷却方法などによつて変化することが知られている. しかしその詳細については不明の点が多く, 詳しい観察 が必要とされている。一方セレーションの発生挙動を観 察するだけではセレーションの生じ方とそれらの因子と の関係を統一的, 定量的に理解し, 金属材料を極低温の 構造部材として使用した場合や材料試験時におけるセ
レーションの発生状況，その影響を予測することは困難 である。もし計算機を用いてセレーションをうまくシ ミュレートできればこのような困難はかなり低減するも のと考えられる．極低温でのセレーションの計算機シ ミュレーションに関しては, 今日までにいくつかの研究

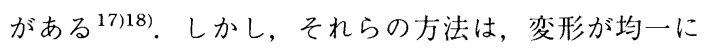
生じるとしていること, 試験片の形状の影響を調べるこ とができないこと，計算に用いられているパラメーター に物理的意味の不明確なものがあることなどの欠点を有 している.そこで, できる限り物理的意味の明らかな式 やパラメーターを用いて, 変形の不均一性をも含め実際 を良く再現できるシミュレート方法を見い出すことを目 的として研究を行つた.

\section{2. 実 験 方 法}

\section{$2 \cdot 1$ 引張試験}

シミュレーションによつて得られる結果と実際に得ら れる結果を比較するためと計算に用いるパラメーターの 值を得るために, Table 1 に示すような化学組成を有 する Fe-Ni 合金を室温, 液体窒素中, 液体へリウム中 
Table 1. Chemical composition in wt $\%$.

\begin{tabular}{c|ccccc}
\hline Alloys & $\mathrm{Ni}$ & $\mathrm{C}$ & $\mathrm{N}$ & $\mathrm{Al}$ & $\mathrm{Fe}$ \\
\hline $\mathrm{A}$ & 41.7 & 0.001 & 0.0007 & 0.052 & Balance \\
$\mathrm{B}$ & 39.5 & 0.001 & 0.0007 & 0.051 & Balance \\
\hline
\end{tabular}

等で引張試験した。この合金系を選んだ理由は，低温で の相の安定性 ${ }^{19)}$, 熱特性のデー夕 ${ }^{20) 21)}$ が比較的よく揃 つているからである.供試材を液体へリウム中で引張り, 破断部を組織観察したが, マルテンサイトはB 合金でご くわずか観察されただけで $\mathrm{A}$ 合金ではまつたく観察され なかつた。また $5 \%$ 程度までの引張変形では，両合金 ともマルテンサイトも変形双晶もほとんど生じないこと が観察された。供試材は真空誘導炬にて溶解し，鋳塊を 熱間圧延した後 $1373 \mathrm{~K} て ゙ 1 \mathrm{~h}$ 加熱してから, 平行部の 長さが $10 \mathrm{~mm}$ の丸棒引張試験片に加工した。ねじ部の 直径は $12 \mathrm{~mm}$ と一定にしたが平行部の直径は $4 \mathrm{~mm}, 5$ $\mathrm{mm}, 6 \mathrm{~mm}$ のものを用意した. 引張試験は油圧式試験機 を用い, アクチュエーターの駆動速度を弾性変形域にお ける歪み速度が拈よそ $3 \times 10^{-3} \mathrm{~s}^{-1}$ となるように設定し た。このとき塑性変形域での歪み速度は平均およそ 1.0 $\times 10^{-2} \mathbf{S}^{-1}$ となつた，試験片は電解研磨して表面の加 工層を除いた後引張試験に供した.試験片 (平行部とテー パー部）の伸びは別報5)に示すように試験片にとりつけ たクリップゲージにて感度良く検出した。試験結果は荷 重一伸び曲線, 荷重-時間曲線あるいは伸び-時間曲線と してペンレコーダーに記録した。

\section{$2 \cdot 2$ シミュレーション方法}

テーパー部を含め試験片を長さ方向に垂直に $N$ 個の 円盤に分割し，さらにそれぞれの円盤を半径 $0.5 \mathrm{~mm}$ 間 隔の同心円状に幅の等しい $M$ 個のリングと円盤に分割 する.これらの要素において, 以下に述べる $2 \cdot 2 \cdot 1$ か ら $2 \cdot 2 \cdot 4$ の計算を繰り返し, 応力-伸び曲線, 温度-伸 び曲線, あるいは試験片長さ方向の直径の分布曲線など を得た。

$2 \cdot 2 \cdot 1$ 塑性変形量, 転位密度の増加, 加工硬化の計 算

塑性変形速度 $\left(\dot{\varepsilon}_{P}\right)$ は

$$
\dot{\varepsilon_{P}}=(1 / 3.06) \dot{\gamma}_{P}=(1 / 3.06) n b v
$$

なる式から求めた。ここで, 係数 $(1 / 3.06)$ は多結晶体 の各結晶粒で生じる多重すべりの効果を表すものであ $3^{22)} \cdot \dot{\gamma}_{P}$ はせん断変形速度, $n$ は可動転位密度, $b$ はバー ガースベクトル, $v$ は転位。運動速度で,

$$
v=A \exp (-U / R T) \text {. }
$$

より求めた. $R$ は気体定数, $T$ は絶対温度, $U$ は活性 化エネルギーである．Aは転位の運動の素過程に関連
する定数である．転位の運動の素過程に関してはいまだ 不明の点が多く残されている ${ }^{23)}$ が, 本研究では $A$ と $U$ の大きさを試みに以下のように評価した。 まず $A$ につ いては長さ $D$ の転位が一つの抵抗を乗り越えるか固着 点を離脱するときに, 変形方向に移動できる距離を $\theta D$ とする. $\theta$ は転位の運動の素過程がどのようなものであ るかによつて異なる定数である。このとき転位の力学的 平衡が崩れることや，慣性力の効果などにより，続けて 乗り越えることのできる抵抗の数あるいは離脱すること のできる固着点の数を $j$ とすると，

$$
A=j \theta D \nu
$$

と表せる ${ }^{24)}$. $\nu$ は転位の振動数で, DEBYE の振動数を $\nu_{D}\left(\fallingdotseq 10^{13} \mathrm{~s}^{-1}\right)$ とすると $\nu_{D} b / D$ の程度の大きさと見 積もれる。これらを（1）式に代入すると（1）式は

$$
\begin{aligned}
\dot{\varepsilon}_{P} & =(1 / 3.06) n j \theta b^{2} \nu_{P} \times \exp (-U / R T) \\
& =A_{0} n \exp (-U / R T) \cdots \cdots \cdots \cdots \cdots \cdots
\end{aligned}
$$

となる．いま仮に, $j \theta=1, \quad b=(3.60 / \sqrt{2}) \times 10^{-10} \mathrm{~m}$ とすると

$$
A_{0}=2.12 \times 10^{-7} \mathrm{~m}^{2} \mathrm{~s}^{-1}
$$

となる.

一方，Uは転位に㗢く有効応力 $\left(\sigma_{e f f}\right)$ の関数として 表すことができる．本研究では現在までに提唱されてい る ${ }^{25)}$ そのよな関数のうち Mott-Nabarro の式

$$
\begin{aligned}
& U / U_{0}=\left[1-\left(\sigma_{e f f} / \sigma_{0}\right)^{2}\right]^{1 / 2} \\
& \quad-\left(\sigma_{e f f} / \sigma_{0}\right) \cos ^{-1}\left(\sigma_{e f s} / \sigma_{0}\right) .
\end{aligned}
$$

を用いた， $U_{0}, \sigma_{0}$ は定数で， $\sigma_{e f f}=0$ のとき $U=U_{0}$, $\sigma_{e f f}=\sigma_{0}$ のとき $U=0$ となる. $U_{0}$ が大きいと材料の強 度の温度依存性が大きく, $\sigma_{0}$ が大きいと強度レベルが 上がる。 $U_{0}$ の值を実際に求めた文献を見い出せなかつ たので，極低温クリープのデータより求められている各 種金属の $U_{0}$ 值 $^{26)}$ などを参考にして適当な值を代入し

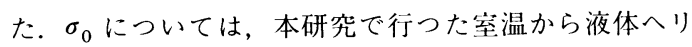
ウム温度に扔ける引張試験結果より変形抵抗の非熱活性 成分 $\left(\sigma_{a t h}\right)$ を推定し, 計算より求めた応力一伸び曲線の 強度レベルが実際に得られた強度レベルとほほ同様とな るような值を用いた。

塑性変形による転位の増殖は,

$$
n=n_{0}+\alpha\left(\varepsilon_{P}\right)^{1 / 2}
$$

に従つて生じると仮定して計算した。ここで， $\varepsilon_{P}$ は塑 性変形量 (歪み), $n_{0}$ は初期可動転位密度, $\alpha$ は定数で ある. 初期可動転位密度の值としては, 供試材が溶体化 処理材であることを考虑して $10^{11} \mathrm{~m}^{-2}$ 程度とした ${ }^{27)}$. また，（5）式に

$$
\begin{aligned}
\sigma_{e f f} & =\left(\sigma_{\text {appl }}-\sigma_{\text {ath }}\right)-\omega\left(n-n_{0}\right)^{z} \\
& =\left(\sigma_{\text {appl }}-\sigma_{\text {ath }}\right)-\omega\left(\alpha \varepsilon_{p}^{1 / 2}\right)^{z} \cdots
\end{aligned}
$$


を代入することによつて加L硬化を考虑した。 $\omega, z$ は 加工硬化の程度を表す定数で, 計算では $z=1$ とした. $\alpha, \omega$ は実際の忍力-伸び曲線の加工硬化の程度に合うよ うに選んだ， $\sigma_{a p p l}$ は付加応力である， $\sigma_{a t h}$ は一般にヤ ング率の温度依存性に相当する程度の温度依存性を有す る.しかし，本研究ではアンバー合金のヤング率が 4.2 $\mathrm{K}$ から $200 \mathrm{~K}$ の範囲で $2 \%$ 弱しか変化しない ${ }^{20)}$ ので温 度依存性は無視した。なお, 転位の増殖, 加工硬化を考 慮しなくてもセレーションは計算で生じさせることはで きるが, 伸びの増加とともにセレーションが大きくなる というような実際の観祭結果に計算結果を近づけること はできない.

\section{$2 \cdot 2 \cdot 2$ 変形の拘束}

まず変形の拘束を考えずに時間 $t$ の微少間隔 $\Delta t$ 間の 塑性伸びを各要素について計算してから, 以下のような 仮定のもとに，隣り合う要素間における変形の拘束を考 慮した。計算過程の模式図を Fig. 1 に示す。

(1) 各円盤内の要素の塑性伸びの平均值をその円盤の 塑性伸びとする. 平均は要素の断面積 $S$ (塑性変形して も体積は変化しないと仮定して計算した）で重みをつけ て計算した (1st step).

(2) (1)で求めた隣り合う $k-1$ 番目, $k$ 番目, $k+1$ 番 目の円盤の拘束を考虑しない場合の塑性伸びをおのおの $P E(k-1), P E(k), P E(k+1)$ とする. $k$ 番目の円盤を はさむ両側の接合面における歪みは，隣り合う円盤が互

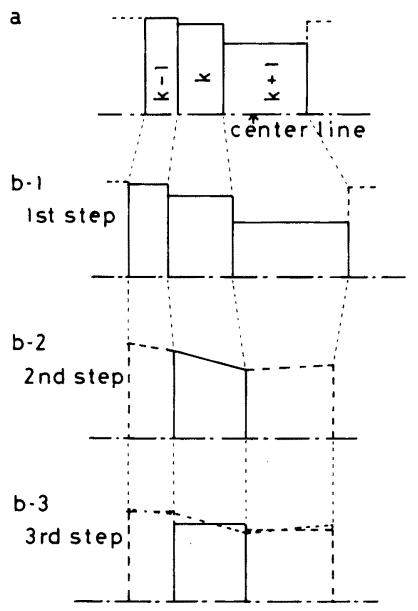

(a) and (b) show elements of the specimen before and after the deformation during $\Delta t$, respectively. (b-1): Without considering the constraint, (b-2): After considering the constraint, (b-3) : After deforming the element geometry for computation convenience.

Fig. 1. Schematic diagrams showing simulation process of considering deformation constraint.
いに拘束し合つておのおの近似的に

$$
\begin{aligned}
& {[\operatorname{PE}(k-1)+P E(k)] / 2} \\
& {[P E(k)+P E(k+1)] / 2}
\end{aligned}
$$

に対応する歪みになるとし， $k$ 番目の円盤は円錐台の形 となる (2nd step) と考える.ついであとの計算が行い やすいように，この円錐台を再度上の二つの值を平均し た塑性伸びを有する円盤とみなす（ 3 rd step).

\section{$2 \cdot 2 \cdot 3 \Delta t$ 間の荷重増分の計算}

$\Delta t$ 間のアクチュエーターの駆動距離 $\Delta Y$ (一定と考 える) は

$$
\Delta Y=\Delta L_{E R}+\Delta L_{E}+\Delta L_{P}
$$

と表せる. $\Delta L_{E R}, \Delta L_{E}, \Delta L_{P}$ はそれぞれプルロッドを 含めた試験機の弾性伸び増分, 試験片の弾性伸び増分, 試験片の塑性伸び増分で, 以下のように表される。

$$
\begin{aligned}
& \Delta L_{E R}=\left(1 / E_{R}\right)\left(\Delta P / S_{R_{0}}\right) L_{R_{0}} \\
& \Delta L_{E}=(1 / E)\left(\Delta P / S_{0}\right) L_{0} \cdots \\
& \Delta L_{P}=\dot{\varepsilon_{P}} \Delta t L_{0} \ldots \ldots \ldots \ldots \ldots \ldots \ldots \ldots \ldots \ldots \ldots \ldots
\end{aligned}
$$

ここで, $E, S, L$ は試験片とプルロッドのおのおのヤ ング率, 断面積, 長さで, 添字 $R$ はプルロッド, 添字 0 は初期值を表す．試験片のヤング率はアンバー合金の 文献值 ${ }^{28)}$ を用いた。温度による $E, E_{R}$ の变化は無視し た. $\Delta P$ は荷重増分で, $(10) \sim(12)$ 式を（9）式に代 入することによつて求められる。 なお，(10) 式では試 験機の弾性伸び増分のうちプルロッド以外の弾性伸び増 分を区別して数式化すると複雑化するし困難も伴うの で，近似として試験機の弾性変形をプルロッドの弾性変 形の中にすべて含めている.

\section{$2 \cdot 2 \cdot 4 \Delta t$ 間の温度上昇}

$\Delta t$ 間の塑性変形による発熱量 $\Delta q$ を以下の式より求 めた。

$$
\begin{aligned}
& \Delta q=c_{0} V^{\prime} \varepsilon_{p} \Delta t \\
& \times\left[\sigma_{\text {appl }}(t)+\sigma_{\text {appl }}(t+\Delta t)\right] / 2
\end{aligned}
$$

$c_{0}$ は定数で $0.4 \sim 0.6^{28)}$ や $1.0^{1)}$ としている報告もある

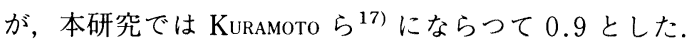
$V^{\prime}$ は要素の体積である.

隣り合う要素間の $\Delta t$ 間における熱伝導量 $\Delta q_{c}$ は

$$
\Delta q_{c}=k(T)(d T / d x) \mathrm{S}_{1} \Delta t
$$

なる式より求めた. $k(T)$ は温度 $T$ における熱伝導度 である，文献 ${ }^{21)}$ によると， $\mathrm{Ni}$ 量による $k(T)$ の違いは 小さいのでアンバー合金のデータ ${ }^{21)}$ を用いた。 $T$ は考 えている $\Delta t$ 間の初期温度である. 温度勾配 $(d T / d x)$ は

$$
\begin{aligned}
& (d T / d x)= \\
& \quad[T(k, l)-T(k-1, l)] / \\
& \quad\{[L D(k, l)+L D(k-1, l] / 2\} \\
& \quad(k=1 \sim N, l=1 \sim M) \cdots \cdots \cdots \cdots . . .
\end{aligned}
$$


より求めた. $L D$ は各要素の熱流方向の厚さである. (14) 式の $S_{1}$ は隣り合う要素間の接触面積で, それらの要素 の面積の平均値を用いた。

$\Delta t$ 間の熱伝達量 $\Delta q_{t}$ は

$$
\Delta q_{t}=q\left(\Delta T^{\prime}\right) S_{2} \Delta t
$$

なる式より求めた。 $q\left(\Delta T^{\prime}\right)$ は液体へリウムあるいは 液体窒素とそれらに接している試験片の最外要素との温 度の差が $\Delta T^{\prime}$ のときの熱伝達による熱流束で, BRENTARI ら ${ }^{29)}$ のデー夕を用いて計算した。 BRENTARIらによ ると, $q\left(T^{\prime}\right)$ は多くの材料でほぼ同じ值を示すので, 計算では $q\left(T^{\prime}\right)$ の材料による違いは考慮しなかつた. $S_{2}$ は冷媒と最外要素との接触面積である.

$\Delta t$ 間の温度増分 $\Delta T$ を求めるには，まずあらかじめ 比熱 $c_{P}$ の温度依存性に関する文献デー夕を参考にして

$$
Q(T)=\int_{T_{0}}^{T} c_{P}(T) d T
$$

を計算し， $T$ より $Q(T)$ が求まるようにしておく. $T_{0}$ は冷媒の温度である。

$$
\Delta Q=\Delta q+\Delta q_{c}
$$

あるいは

$$
\Delta Q=\Delta q+\Delta q_{c}-\Delta q_{t}
$$

とすると, $\Delta T$ は, 方程式

$$
Q(x)-Q(T)-\Delta Q=0
$$

の根 $x(=T+\Delta T)$ より求められる. $\mathrm{Ni}$ 量による $c_{P}$ の 違いは, $\mathrm{Fe}-\mathrm{Ni}$ 合金に関する文献データ21) を内挿，外 挿して求めた。 $4.2 \mathrm{~K} に お け る \mathrm{~A}$ 合金, $\mathrm{B}$ 合金の $c_{P}$ の 值を示すと，おのおのおよそ $1.3 \times 10^{-4}, 1.6 \times 10^{-4}$ $\mathrm{cal} /(\mathrm{g} \cdot \mathrm{K})$ である.

\section{$2 \cdot 3$ 計算に用いたパラメーターの值}

本研究の計算において用いたパラメーターの值をまと めて Table 2 に示す. $\sigma_{0}$ の值は $\mathrm{A}$ 合金 $350 \mathrm{MPa}, \mathrm{B}$ 合 金 $450 \mathrm{MPa}$ とした。 $\sigma_{a t h}$ の值は液体へリウム温度から $20^{\circ} \mathrm{C}$ の温度範囲での引張試験の結果（後述）を参考に

Table 2. Typical values of parameters used in the simulations.

\begin{tabular}{l|l}
\hline Parameters & \multicolumn{1}{c}{ Values } \\
\hline$E_{R}$ & $0.3 \times 10^{5}(\mathrm{MPa})$ \\
$S_{R 0}$ & $0.03^{2} \times(\pi / 4)\left(\mathrm{m}^{2}\right)$ \\
$L_{R 0}$ & $0.5(\mathrm{~m})$ \\
$E$ & $1.42 \times 10^{5}(\mathrm{MPa})$ \\
$S_{0}$ & $0.005^{2} \times(\pi / 4)\left(\mathrm{m}^{2}\right)$ \\
$L_{0}$ & $0.01(\mathrm{~m})$ \\
$v=\Delta Y / \Delta t$ & $1.0 \times 10^{-4}\left(\mathrm{~ms}^{-1}\right) *$ \\
$n_{0}$ & $10^{11}\left(\mathrm{~m}^{-2}\right)$ \\
$\alpha$ & $10^{11}\left(\mathrm{~m}^{-2}\right)$ \\
$\omega$ & $1.5 \times 10^{-9}\left(\mathrm{MPa}^{2}\right)$ \\
$A_{0}$ & $2.12 \times 10^{-7}\left(\mathrm{~m}^{2} \mathrm{~s}^{-1}\right)$ \\
$U_{0}$ & $3.6 \times 10^{4}\left(\mathrm{~J} \cdot \mathrm{mol}^{-1}\right)$ \\
\hline
\end{tabular}

* Strain rate in elastic range $\doteqdot 3 \times 10^{-3} \mathrm{~s}^{-1}$
して A 合金， B 合金とも $200 \mathrm{MPa}$ とした。この值は大 き過ぎることも考えられるが，より小さな值を用いても 両合金の塑性変形挙動の相違を定性的に比較する範囲内 では結果に大きな影響を及ぼさない．長さ力问の分割の 数は試験片平行部（長さ $10 \mathrm{~mm}$ ) 25 , 画側のテーパー 部（長さおのおの $4 \mathrm{~mm}$ ) それぞれ 10 とした。試験片 の直径は $5 \mathrm{~mm}$ とし径方向の分割の数は 5 とした．時間 間隔 $\Delta t$ は $1.0 \times 10^{-4} \mathrm{~s}$ である.

\section{3. 結果}

\section{$3 \cdot 1$ 引張試験}

Fig. 2 に応力-伸び曲線の一部を示す. 試験片の平行 部直径は $5 \mathrm{~mm}$ である。 $\mathrm{A}$ 合金に比べ $\mathrm{B}$ 合金の強度レ ベルが全体に高く，七レーションの大きさ（荷重低下の 大きさあるいは荷重低下の際の伸びの程度）も大きい.

Fig. 3 は， $0.2 \%$ 耐力が試験温度によつてどう変化す るかを示したものである，液体へリウム中での值は，七

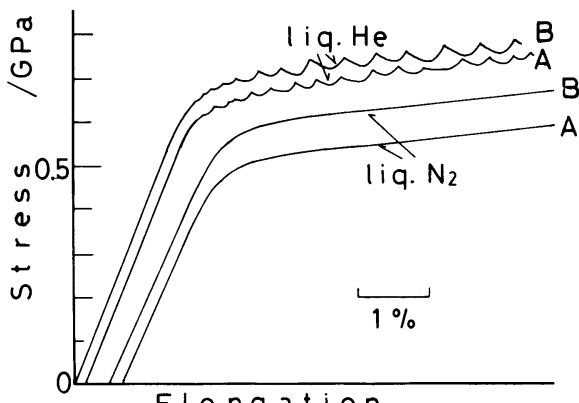

Elongation

Fig. 2. Stress-elongation curves of alloys A and B.

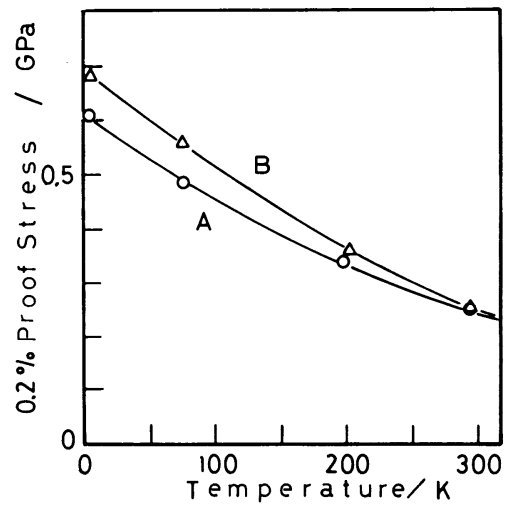

Fig. 3. Temperature dependence of $0.2 \%$ proof stress of alloys $\mathrm{A}$ and $\mathrm{B}$. 


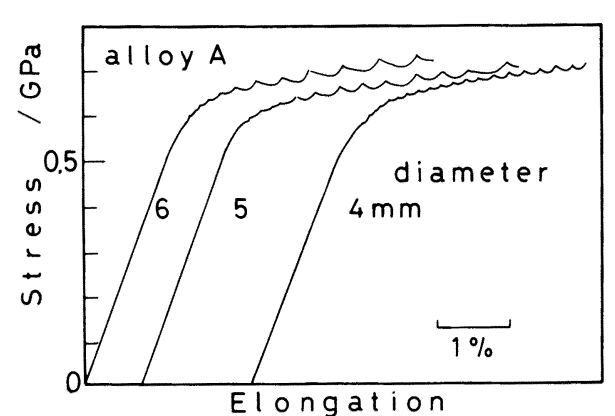

Fig. 4. Stress-elongation curves of alloy A with different diameter.

レーションがすでに生じているため荷重-伸び曲線の上 部包絡線を描いて求めた，䇪温付近では $\mathrm{A}$ 合金と B 合金 の $0.2 \%$ 耐力にそれほど違いが認められないが, 試験 温度が低下するに従つて差が大きくなり，A 合金の耐力 はB命金の耐力より全体に低い。

Fig. 4 は液体へリウム中における A 合金のセレー ションの生じ方に及ぼす試験片太さの影響を示したもの である、試験片平䘕部が太くなるほどセレーションの大 きさが大きくなることがわかる.

\section{$3 \cdot 2$ 計算機シミュレーション}

Fig. 5 に $\mathrm{A}$ 合金と $\mathrm{B}$ 合金を液体へリウム中及び液体 窒素中で $3 \%$ まで引張つた際の応力ー伸び曲線のシ ミュレーション結果を示す。細部を除けばおのおのの荷 重低下の生じ方, セレーションが伸びとともに大きくな る様子など Fig. 2 に示した実際のセレーションの特徵 が良く再現されており，七レーションの大きさも $\mathrm{A}$ 合金 よりB合金で人きくなつている. 曲線にところどころ欠 けたところがあるが、これは逐時的に計算を行つた際の 時間間隔 $\Delta t$ の間に大きな変形が生じたことをあらわ す. Fig. 5 には試験片中央部の最も内側の要素の温度 変化曲線も示した。 セレーションのおのおのの荷重低下 に対応して温度が上昇しているが, 実際变形中の試験片 の温度を測定すると類似の温度変化曲線が得られ $3^{14) 30)}$. 㲸中液体へリウム中での結果において荷重低 下が開始する時点と温度上昇が認められる時点とがずれ ている場今がある，それは温度変化をみている位置から 離れた䈯所で発熱が生じたことによるものである，液体 窒素中での結果では, セレーションがみられなくなると ともに液体へリウム中の結果に比べ強度レベルが低下し ている.この傾问も実際を良く再現している.

Fig. 6 はB 合金を計算のうえで $3 \%$ まで引張つた直 後の試験片产さ力向の直径と温度の分布である。温度分
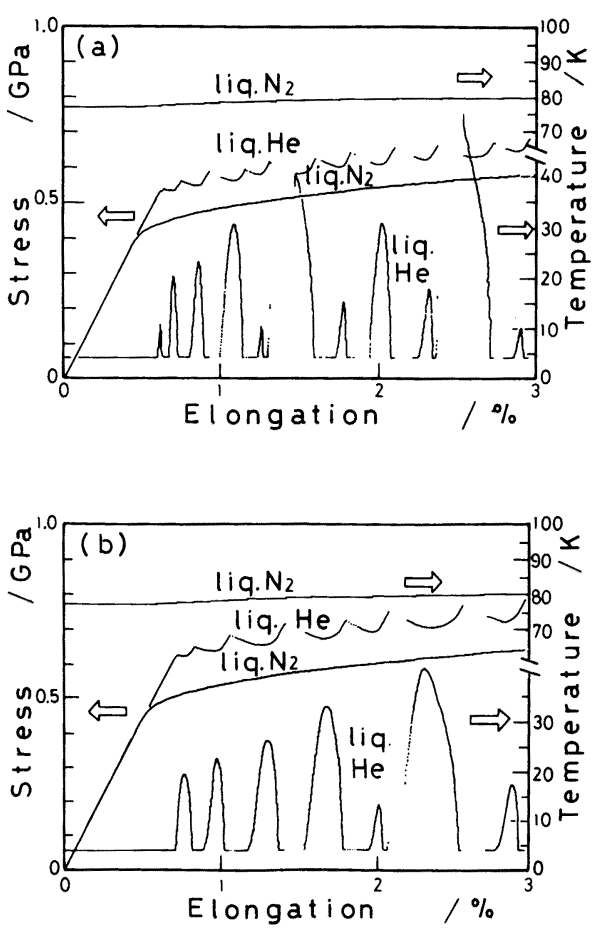

(a) is for alloy A and (b) for alloy B.

Fig. 5. Stress-elongation and temperature-elongation curves obtained by the simulation.

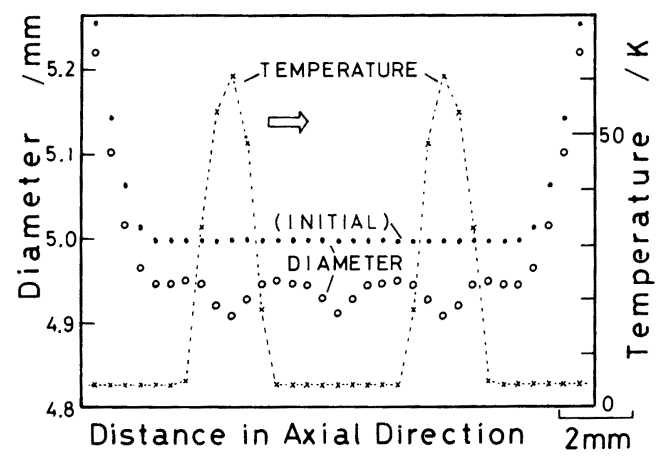

Fig. 6. Simulated profiles of diameter and temperature in the axial direction of the specimen of alloy B at the instant of elongating by $3 \%$ in liquid helium.

布曲線に見られるピークはその位置付近で生じている不 均一変形によるものである。

Fig. 7 は A 合金において試験片の平䘕部の直径を変 化させた場合のシミュレーション結果である. Fig. 3 の結果と同様試験片が太くなるに従つてセレーションが 


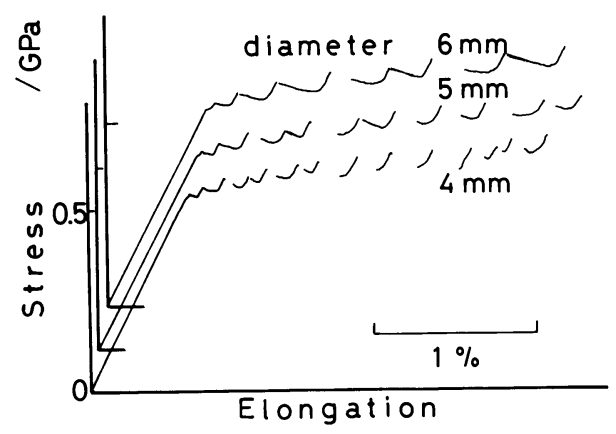

Fig. 7. Simulated stress-elongation curves of specimens with different diameter.

大きくなつている.

以上より，前章で述べたシミュレーション法により極 低温におけるセレーションが比較的良く再現できること が分かつた，本報告ではふれることはできなかつたが， このシミュレーション法を用いると，七レーションに及 ぼす引張速度の影響や, 変形中に生じるマルテンサイト 変態の影響 ${ }^{30)}$, 試験片の形状の影響なども検討するこ とができる、それらについては別に報告することにして， 以下にセレーションに及ぼす各パラメーターの効果, 本 研究におけるシミュレーション方法の課題等について検 討する。

\section{4. 考察}

\section{$4 \cdot 1$ セレーションの大きさに及ぼす強度レベルと比熱 の影響}

KUBIN らのシミュレーション法 ${ }^{18)}$ によると, 強度レ ベルが上がるとセレーションの大きさが小さくなる，し かし一般にはFig. 2 に示したように強度の高い材料の ほうが大きなセレーションを示すことが知られている. 本研究のシミュレーション法によると, Fig. 5 に示し たように強度の高いB合金のセレーションのほうが大き く，実験結果と対応する．ただし Fig. 5 を得た計算で は $\mathrm{A}$ 合金と $\mathrm{B}$ 合金とで強度レベルだけでなく比熱も変え ている。そこで，セレーションの大きさに及ぼす強度レ ベルと比熱の影響を分離して計算してみた. Fig. 8 は その結果で，曲線 1 および 4 はそれぞれ Fig. 5 に示し たものと同じ B 合金，A合金の曲線である．曲線 2 は曲 線 4 の計算に用いたパラメーターのうち $\sigma_{0}$ だけを 350 $\mathrm{MPa}$ から $450 \mathrm{MPa}$ へ夫くして計算したものである. セレーションの発生頻度, 応力の低下の程度が, 曲線 1 のそれらと近いものとなつている. 曲線 3 は曲線 4 の計

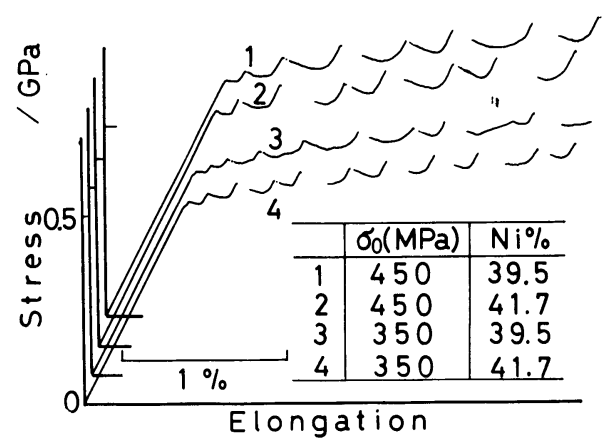

Fig. 8. Simulated stress-elongation curves showing the effects of strength level and specific heat. In the calculation, input of the values of parameters concerning strength level were performed independently from $\mathrm{Ni}$ content which was treated to affect only specific heat.

算に用いたパラメーターの值のうち比熱だけをB合金に 対応する値に変えて計算したものである. セレーション の発生の様子は曲線 4 の場合とそれほど変わらない†. 従つて曲線 1 と曲線 4 の特徵の差は主として強度レベル の違いによるものと言える。しかし強度レベルの違いは $\sigma_{a t h}$ の差によつても生じる. そこでセレーションの大き さに及ぼす $\sigma_{a t h}$ の効果も計算により調べた，具体的な 結果は示さないが， $\sigma_{a t h}$ を大きくするとセレーションは 大きくなる傾向にあつた，結局，KUBIN らの方法との不 一致が何によるのか明らかでないが，強度レベルが高く なるとセレーションが大きくなるという一般的な観察事 実が, 本研究のシミュレーション法で再現されることが わかつた

\section{$4 \cdot 2$ 塑性変形の来過程}

前章で、マルテンサイト変態や変形双晶を考虑しなく ても，セレーションが計算によつて良く再現できること が分かつた。このことは, セレーションの発生機構とし て前述した転位の運動とそれによる塑性仕事にもとづく 発熱を原因に考える機構が基本的に正しいことを示すも のと考えられる. しかし, 転位の運動の素過程に関して は不明の点が多く，この点に関する部分に不確かさを残 している，例えば，本研究で用いた $\mathrm{Fe}-\mathrm{Ni}$ 合金の主要 な強化機構を固溶強化と考えても, ごく最近の研究レ ビュー23)に述べられているように固溶強化機構に関す る理解はいまだ不十分なようである，また，耐力は $\mathrm{Ni}$ 量の多いA合金のほうが低く，とくに低温になるほど違 いが顕著になるという結果が得られたが,これは一般的

† $C_{P}$ の值をさらに大きくするとセレーションの発生頻度が明らかに增 すことを示す結果が別に得られている. 
な固溶強化理論からは説明できない。 $\mathrm{ECHIGOYA}^{31)} ら は$ $\mathrm{Fe}-\mathrm{Ni}$ 合金の強度は $37 \mathrm{wt} \%$ 付近で極大となること, この組成付近の合金の強度の温度依存性が大きいことを 報告しており，この現象を，アンバー効果によつて邓状 転位に働く磁気的な強化作用から説明している。 そのよ

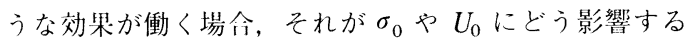
か喽細は明らかでないが，アンバー組成に近い合金のほ うが強度の温度依你性が大きいことから， $U_{0}$ もきい ことが推察される。そこで， $U_{0}$ がセレーションに及ほ す効果をシミュレートしてみたが， $U_{0}$ だけを大きくす るとセレーションの大きさは小さくなることがわかつ た. 従つてシミュレーション結果から判断するかぎり, アンバー組成に近いB命金のほうがセレーションが大き いことを $U_{0}$ が大きいということからは説明できない. 転位の運動を律速する機構により $A_{0}$ も変化することが 考えられる．現状では， $A_{0}$ の值を確定することはでき ないので，七レーションに拈よ゙す $A_{0}$ の影響もシミュ レーションにより検討した。 その結果 $A_{0}$ を大きくする とセレーションが大きくなることがわかつた。転位の運 動の素過程は，さらに，極低温で転位の運動に特異性が 生じることや ${ }^{32)}$, 温度域によつて異なる機構が働く ${ }^{26)}$ ことなども考えられ複雑である. 本報告で述べたセレー ションのシミュレーション法は，いろいろな実験事実を 良く再現し有用なものであることが分かつたが，転位の 連動に関する基礎的研究がさらに進展することが期待さ れる。

\section{$4 \cdot 3$ 試験機の剛性の効果}

3 章に示したシミュレーション結果ではプルロッドの ヤング率 $\left(E_{R}\right)$ を $30 \mathrm{GPa}$ としている。この值は実際に 用いたプルロッドの材料である SUS 316 鋼のヤング率 の值，およそ $200 \mathrm{GPa}$ よりかり小さい.プルロッド のヤング率に小さな值を代入したのは，大きな值を用い ると油圧式試験機を用いて実験的に得られるセレーショ ンとかなりかけ離れた形の忍力ー伸び曲線となつてしま うからである。計算においてプルロッドのヤング率とし て扱つた項は本来試験機全体のヤング率すなわち試験機 の剛性として考虑されるべきものである。一方従来より セレーションの生じナは試験機の剛性によつて変化する ことが知られている ${ }^{16)}$. 本研究で用いた試験機の剛性 がどの程度のものか調べられなかつたが, 油圧式である ことを考えるとかなり低いことが推祭される．計算上プ ルロッドのヤング率として扱われる試験機の剛性がシ ミュレーションによるセレーションにどのように影響す るのか調べた結果の一例を Fig. 9 に示す. 曲線 3 は Fig. 5 に示したA令金の曲線と同じもので， $E_{R}$ は 30

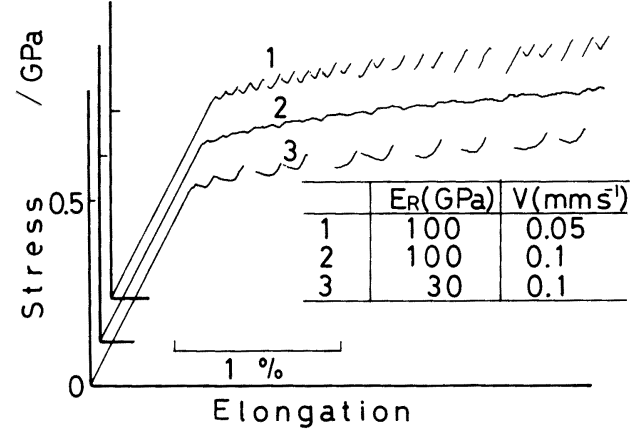

Fig. 9. Simulated stress-elongation curves showing the effects of the machine stiffness and the driving speed of the actuator.

$\mathrm{GPa}$ である。曲線 2 は $E_{R}$ を $100 \mathrm{GPa}$ にした場令のも ので，七レーションが不明瞭になつている．ただしこの 場合忍力ー伸び曲線の弾性变形領域に抢ける歪み速度が 曲線 3 の場合よりおよそ2 倍速くなつてしまつている.

これはアクチュエーターの駆動速度 $V$ を一定にして試 験機の剛性を大きくした場合，（9）式からも分かるよ うに単位時間内のプルロッドの弾性変形量が減少しただ け試験片の弾性変形量が増すためである，そこでこの領 域での歪み速度が曲線 3 の場合と同じ程度となるよう に, $V$ を $1 \times 10^{-4} \mathrm{~m} \mathrm{~s}^{-1}$ から $5 \times 10^{-5} \mathrm{~m} \mathrm{~s}^{-1}$ に小さ した場合のセレーション挙動を調べた。曲線 1 がその結 果である. 荷重低下の数が非常に多くなつている．この 結果は, 試験機のばね定数を变化させてセレーションへ の影響を実験的に調べた CHIN ら ${ }^{16)}$ の結果と定性的に一 致する.

\section{$4 \cdot 4$ セレーションにおける荷重低下のきつかけ}

極低温で生じるセレーションの発生機構に関して今日 までに提唱されている説を整理すると, 変形双晶 ${ }^{33)}$, マルテンサイト ${ }^{34)}$ あるいは堆積転位の急速な運動 ${ }^{35)}$ が 生じるときの忘力緩和に原因を求めるもの（以下力学的 機構と呼ぶ）と, 变形の際の発熱を重視するもの（以下 熱的機構と呼ぶ）とに大別できる. セレーションは変形 双晶やマルテンサイトが生じない材料でも観察され

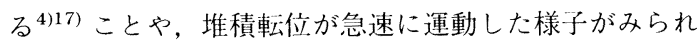

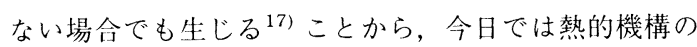
ほうがより一般的なものとして重要視されている．しか し熱的機構の場合でも, 発熱のきつかけとして例えば堆 積転位の急速な運動の開始 ${ }^{12) 28)}$ などのなんらかの特別 な現象が生じることが必要であるとするもの出と，とく にそのような現象が生じなくてもセレーションは生じる とするもの7)15/17)18) とがある. 本研究のシミュレーショ 
ン結果は実際のセレーション挙動を良く再現することが 分かつたが，計算に拝いてはセレーションのきつかけと なるようなものは特別に考慮していない，すなわち，七 レーションはきつかけとなる特別の現象がなくても熱バ ランスとそれと関連した試験片の温度変化が転位の連動 速度に与える効果の結果として生じ得るということがわ かる、ただしこのことは, 双晶変形, マルテンサイト変 態, 堆積転位の急速な運動などが生じる場合, それらの 効果を否定するものではない，それらによる応力の緩和， 発熱も当然セレーションの発生に影響を及ぼすことは考 えられる. しかしその場合それらの影響がどの程度のも のなのか, 定量的に評価する必要が残されている.

\section{5. 結 論}

変形が局所的に生じることを含め, 極低温での変形挙 動をできるだけ良くシミュレートする方法を見いだすこ とを目的として, $\mathrm{Fe}-\mathrm{Ni}$ 合金を室温から液体ヘリウム 温度の範囲で引張試験して得られた忍力-伸び曲線と比 較しながら，熱活性化による転位の運動方程式と熱バラ ンスの式を組み合わせた計算機シミュレーション法を検 討した。その結果, 固溶強化理論や極低温での転位の運 動の素過程に関する理解の現状に起因する不十分さはあ るものの, 本研究で用いたシミュレーション法により比 較的無理なくいろいろな実験事実を良く再現できること がわかつた.

最後に，供試鋼の溶解を打願いした川崎製鉄に深謝致 します。シミュレーションのプログラム作成と極低温で の実験に協力いただいた小田克郎君, 志賀英俊君, 藤田 庫造君, 栗田真人君, 東京大学低温センターに感謝致し ます。また研究費の一部は, 文部省科学研究費助成金 (一 般 C, 昭和 60,61 年度), 岩谷直治研究助成金により ましたことを付記致します。

\section{文献}

1) D. T. ReAd and R.P. ReEd: Advances in Cryogenic Engineering Materials, 26 (1980), p. 91

2) K. Nagai, T. Yuri, Y. Nakasone, T. Ogata and $K$. Ishikawa: Advances in Cryogenic Engineering Materials, 32 (1986), p. 313

3) 柴田浩司, 岸本康大, 河端慎一, 藤田利夫: 鉄と鋼, 70 (1984), S1290
4) Z. S. Basinski: Proc. Roy. Soc., A240 (1957), p. 229

5 ) 柴田浩间, 藤田利夫: 鉄と鋼（投稿中）

6 ) 緒形俊夫，石川圭介，長井 寿，由利哲美: 鉄と鍓，71 (1985), S1462

7) R. L. Tobler: ASTM STP803 (1983), p. 763

8 ）緒形俊夫, 石川圭介: 低温1学, 21 (1986), p. 93

9 ) 島本 進: 低温工学, 20 (1985), p. 113

10）緒形俊夫，石川洼介，長井 表: 鉄と䤱，71 (1985), p. 1390

11）福島英二, 後藤 明: 日本金属学会誌，39 (1975)， p. 182

12) V. A. Moskalenko, V. I. Staktsev and $V . N$. Koval.fiva: Titanium, 80 (1980) 2, p. 821

13) T. Kawabata, $S$. Morita and $O$. Izumi: liij上, p. 801

14）緒形俊大，石川圭介，長井 表: 鉄と鋼，71 (1985), p. 1390

15) E. F. Mkdvedev and E. S. Kirll.lov: Cryogenic, 17 (1977), p. 283

16) G. Y. Chin, $W . F$. Hosford, Jr. and W. A. Backofen: Trans. AIME, 230 (1964), p. 1043

17) E. Kuramoto, S. Takeuchi and T. Suzuki: J. Phys. Soc. of Japan, 34 (1973), p. 1217

18) L. P. Kubin, Ph. Spiesser and Y. Estrin: Acta Metall., 30 (1982), p. 385

19) L. Kaufman and M. Cohen: J. Met. (1956), p. 1393

20) LNG Materials and Fluids-User's Manual and Supplement, 1-2 (1977) [NBS]

21) Thermal Properties of Matter, 1 (1970) 4, TPRC [Plenum]

22) G. I. TAYLoR: J. Inst. Metal, 62 (1938), p. 307

23) U. F. Kocks: Metall. Trans., 16A (1985), p. 2109

24）金属の強さ (鈴木秀次監修)（1972）［アグ衤]

25) K. Ono: J. of Appl. Phys., 39 (1968), p. 1803

26) J. K. TIEN and C. T. YEN: Advances in Cryogenic Engineering Materials, 30 (1984), p. 319

27) A. S. Tetelman and A. J. Mcevl.ey: Fracture of Structural Materials (1967) [John Wiley]

28) R. Zürcher, $V$. Gröger and $F$. Stangl.er: phys. stat. sol. (a), 84 (1984), p. 475

29) E. G. Brentakl and R. V. Smith: Advances in Cryogenic Engineering, 10 (1965), p. 325

30) $K$. Shibata, M. Kurita, $K$. Fujtta and T. Fumta: Proc. of ICOMAT-86 (印刷中)

31) J. Echigoya, S. Hayashi and M. Yamamoto: phys. stat. sol. (a), 14 (1972), p. 463

32) R. Ogawa, M. Shimada and T. Horiuchi: Trans. of Japan Inst. of Metals, 27 (1986), p. 5

33) T. H. Blewitt, $R . R$. Col.tman, and $J . K$. Reiman: J. of Appl. Phys., 28 (1957), p. 651

34) C. J. Guntek and R. P. ReFi: Trans. ASM, 55 (1962), p. 399

35) B. Obst and D. Pattanayak: Advances in Cryogenic Engineering Materials, 28 (1982), p. 57 